Arq. Bras. Med. Vet. Zootec., v.68, n.3, p.620-628, 2016

\title{
Integrity of the plasma membrane, the acrosomal membrane, and the mitochondrial membrane potential of sperm in Nelore bulls from puberty to sexual maturity
}

[A integridade da membrana plasmática, da membrana acrossomal e o potencial da membrana mitocondrial de espermatozoides de touros Nelore da puberdade até à maturidade sexual]

\author{
L.S.L.S. Reis ${ }^{1}$, A.A. Ramos $^{2}$, A.S. Camargos $^{2}$, E. $\mathrm{Oba}^{2,3}$ \\ ${ }^{1}$ Universidade do Oeste Paulista - Presidente Prudente, SP \\ ${ }^{2}$ Unesp-Botucatu - Botucatu, SP \\ ${ }^{3}$ Bolsista de produtividade do $\mathrm{CNPq}$
}

\begin{abstract}
This study evaluated the plasma membrane integrity, acrosomal membrane integrity, and mitochondrial membrane potential of Nelore bull sperm from early puberty to early sexual maturity and their associations with sperm motility and vigor, the mass motility of the spermatozoa (wave motion), scrotal circumference, and testosterone. Sixty Nelore bulls aged 18 to 19 months were divided into four lots $(\mathrm{n}=15$ bulls/lot) and evaluated over 280 days. Semen samples, collected every 56 days by electroejaculation, were evaluated soon after collection for motility, vigor and wave motion under an optical microscope. Sperm membrane integrity, acrosomal integrity, and mitochondrial activity were evaluated under a fluorescent microscope using probe association (FITC-PSA, PI, JC-1, H342). The sperm were classified into eight integrity categories depending on whether they exhibited intact or damaged membranes, an intact or damaged acrosomal membrane, and high or low mitochondrial potential. The results show that bulls have a low amount of sperm with intact membranes at puberty, and the sperm show low motility, vigor, and wave motion; however, in bulls at early sexual maturity, the integrity of the sperm membrane increased significantly. The rate of sperm membrane damage was negatively correlated with motility, vigor, wave motion, and testosterone in the bulls, and a positive correlation existed between sperm plasma membrane integrity and scrotal circumference. The integrity of the acrosomal membrane was not influenced by puberty. During puberty and into early sexual maturity, bulls show low sperm mitochondrial potential, but when bulls reached sexual maturity, high membrane integrity with high mitochondrial potential was evident.
\end{abstract}

Keywords: sexual development, sperm motility, sperm vigor, testosterone, cattle

\section{RESUMO}

Este estudo avaliou a integridade da membrana plasmática, da membrana acrossomal e o potencial da membrana mitocondrial de espermatozoides de touros da raça Nelore da puberdade até à maturidade sexual e suas correlações com motilidade, vigor, turbilhão dos espermatozoides, circunferência escrotal e testosterona. Sessenta touros da raça Nelore, com idade entre 18 e 19 meses, foram divididos em quatro lotes ( $n=15$ touros / lote) e foram avaliados por 280 dias. Coletaram-se as amostras de sêmen a cada 56 dias por eletroejaculação e, logo após, foram determinados a motilidade, o vigor e o turbilhão dos espermatozoides por microscopia óptica. A integridade da membrana de esperma, da membrana acrosomal e da atividade mitocondrial foi avaliada por microscopia de fluorescência, utilizando-se associação das sondas (FITC-PSA, PI, JC-1, H342). Os espermatozoides foram classificados em oito categorias de integridade, dependendo se eles exibiram membranas plasmática e mitocondrial intactas ou danificadas e potencial mitocondrial elevado ou baixo. Os resultados mostram que os touros têm uma baixa quantidade de espermatozoides com membranas íntegras na puberdade, com baixa motilidade, vigor e turbilhão. No entanto, nos touros na maturidade sexual precoce, a integridade da membrana dos

Recebido em 15 de setembro de 2015

Aceito em 7 de janeiro de 2016

E-mail: reis.1sls@gmail.com 
espermatozoides aumentou significativamente. A taxa de dano à membrana espermática foi negativamente correlacionada com a motilidade, o vigor, o movimento das ondas e a concentração de testosterona nos touros, e uma correlação positiva existiu entre a integridade da membrana plasmática e a circunferência escrotal. A integridade da membrana acrossomal não foi influenciada pela puberdade.

Palavras-chave: desenvolvimento sexual, motilidade de espermatozoides, vigor espermático, testosterona, bovino

\section{INTRODUCTION}

The sexual development of bulls from puberty to sexual maturity is characterized by remarkable changes in the physical features of the animal as well as the quality of its semen. Sperm concentration, sperm motility, sperm vigor, and wave motion increase with maturity before reaching a plateau, which improves the potential for fertilization (Neto et al., 2011).

The maintenance of the sperm fertilization potential depends on the integrity and functionality of different cellular structures. Plasma membrane integrity is crucial for sperm survival inside the female reproductive tract to maintain the fertilization capability and the cell's osmotic equilibrium, and acting as a barrier between the intra- and extracellular media (Flesh and Gadella, 2000).

Acrosomal integrity and enzyme maintenance are essential to the acrosomal reaction (Flesh and Gadella, 2000) and membrane fusion is required for sperm-oocyte fusion even though sperm membranes are fixed to oocytes in the free zone and the occurrence of fertilization (Hafez, 2004).

The main physiological function of the mitochondria in sperm is to produce ATP, generating energy for the flagellar beat and sperm motility (Barth and Oko, 1989; Hafez, 2004).

Although reproductive events that occur in bulls from puberty to maturity are often studied, including their hormonal profile, spermatogenesis, sperm progressive motility, sperm morphology, information about the plasma membrane integrity, acrosomal membrane integrity, and the mitochondrial membrane potential of sperm in Nelore bulls is still scarce. This study aimed to evaluate plasma membrane integrity, acrosomal membrane integrity, and mitochondrial membrane potential of sperm of Nelore bull semen from puberty to sexual maturity and correlate these variables with sperm motility and vigor, wave motion, and scrotal circumference.

\section{MATERIAL AND METHODS}

The procedures used in this study were approved by the Ethics Committee on Animal Use of the School of Veterinary Medicine and Animal Science of São Paulo State University, Botucatu, SP, Brazil - Protocol 51/2009-CEEA.

The experiment was conducted in an extensive farming system in the municipality of Lutécia, Brazil, which has a tropical climate with a mean annual precipitation of $1,300 \mathrm{~mm}$ and a mean relative air humidity of $64 \%$. In spring and summer, the average minimum temperature is $20^{\circ} \mathrm{C}$, with a maximum of $30 \mathrm{C}^{\circ}$. In autumn and winter, the average minimum temperature is $14^{\circ} \mathrm{C}$, with a maximum of $25^{\circ} \mathrm{C}$.

We evaluated 60 Nellore bulls (Bos taurus indicus) of a similar age, 18-19 months, that were coming into puberty. These bulls were purchased from four different farms (15 bulls/farm) to increase the genetic variability among the bulls. The bulls were marked with earrings denoting batches $\mathrm{L}_{1}, \mathrm{~L}_{2}, \mathrm{~L}_{3}$, and $\mathrm{L}_{4}$ that corresponded to their farms. The average body weight of the $\mathrm{L}_{1}$ lot bulls was $264.5 \pm 22.5 \mathrm{~kg} ; \mathrm{L}_{2}$ was $261.5 \pm 23.4 \mathrm{~kg} ; \mathrm{L}_{3}$ was $268.5 \pm 19.6 \mathrm{~kg}$, and $\mathrm{L}_{4}$ was $267.9 \pm 22.5 \mathrm{~kg}$.

The experimental period was $280 \mathrm{~d}$ to the point when the bulls reached early sexual maturity (2627 mo of age), and the average body weight of the bulls per lot was as follows: $\mathrm{L}_{1}$ lot was $440.0 \pm 28.7 \mathrm{~kg} ; \mathrm{L}_{2}$ was $422.6 \pm 31.5 \mathrm{~kg} ; \mathrm{L}_{3}$ was $441.9 \pm 25.4 \mathrm{~kg}$, and $\mathrm{L}_{4}$ was $443.9 \pm 39.0 \mathrm{~kg}$.

During the trial period, the bulls were kept in an extensive farming system and fed on a Brachiaria decumbens grass pasture with an ad libitum water supply supplemented with a protein mineral mixture ad libitum. Each $\mathrm{kg}$ of 
the mixture contained $40 \mathrm{~g}$ calcium, $15 \mathrm{~g}$ phosphorous, $89 \mathrm{~g}$ sodium, $15 \mathrm{~g}$ cobalt; $4 \mathrm{~g}$ sulfur, $402 \mathrm{mg}$ copper, $20 \mathrm{mg}$ iron, $2.8 \mathrm{mg}$ selenium, $1,400 \mathrm{mg}$ zinc, $150 \mathrm{mg}$ fluoride, $400 \mathrm{~g}$ crude protein, and $337.50 \mathrm{~g}$ protein equivalent of urea, meeting the nutritional requirements of the bulls according to the National Research Council (NRC, 2000).

The protein-mineral mixture was provided in a feeding trough with $13 \mathrm{~cm}$ available to each animal. A water trough was placed $50 \mathrm{~m}$ from the feeding trough as recommended by the Brazilian Association of Mineral Supplement Industries (ASBRAM, 2003).

The first 60 days of the trial served to adapt the bulls to the experimental conditions, including their management in the corral for semen collection, the pasture and the protein mineral mixture. After this adaption period, semen collection was performed every 56 days (i.e., the time required to complete the spermatogenesis cycle second Mies Filho (1987) until the bulls reached sexual maturity. The semen was collected to evaluate sperm progressive motility, sperm vigor, the mass motility of the spermatozoa (wave motion), the sperm plasma membrane integrity, the acrosomal membrane integrity and the mitochondrial membrane potential. The semen collection matched the seasons: summer, fall, winter, spring and summer of the following year.

Twice during each study period, semen samples were collected by electroejaculation because the bulls were reared in an extensive system of pastures to promote natural mating and were not adapted to semen harvesting through an artificial vagina as previously done by Freneau et al. (2006), Fernandes et al. (2008), and Reis et al. (2014).

The sperm progressive motility, sperm vigor, mass motility of spermatozoa, sperm plasma membrane integrity, acrosomal membrane integrity and mitochondrial membrane potential were determined after the seeds on the farm were harvested. Thus, all of the equipment needed to perform these sperm analyses were brought to the farm.

To determine sperm progressive motility, a drop of fresh semen was placed between a slide and a coverslip and pre-heated to $37^{\circ} \mathrm{C}$ using a board heater. The percentage of sperm with rectilinear movement was then visually estimated under an optical microscope equipped with a platinum heater. The sperm vigor was assessed using scores in a range of $0-5$, where 0 indicated the absence of progressive movement and 5 indicated sperm moving vigorously and rapidly forward (CBRA, 1992). These analyzes were performed by the same investigator throughout the experiment.

After the analyses described above, the semen was diluted in Botu-Bov ${ }^{\circledR}$ (Botupharma, Botucatu, São Paulo, Brazil), to a final concentration of $25 \times 10^{6}$ spermatozoa $/ \mathrm{ml}$. The sperm plasma membrane integrity, acrosomal membrane integrity, and the mitochondrial membrane potential were assessed by fluorescence microscopy (Leika) using a combination of fluorescent probes as recommended by Celeghini et al. (2007): propidium iodide, Hoechst 33342, fluorescein isothiocyanate-Pisum sativum iodide, and 5,5,'6,6-tetrachloro-1,1,3,3-

tetraethylbenzimidazolcarbocyanine. The sperm were classified into eight integrity categories depending on whether they exhibited intact (IMe) or damaged plasma membranes (DMe), intact (IA) or damaged acrosomal membranes (DA), and a high (HM) or low (LM) mitochondrial membrane potential. These analyzes were performed by the same investigator throughout the experiment.

The scrotal circumference of the bulls was measured every 56 days along with semen harvesting. The measurements were taken with a flexible centimeter tape around the point of the greatest diameter of the scrotal sac (CBRA, 1992).

Blood samples were collected from the bulls every $56 \mathrm{~d}$ in the morning after semen collection; $10 \mathrm{~mL}$ of blood were collected by jugular vein puncture and stored in vacuum tubes without anticoagulant. Blood samples were centrifuged at 2,500rpm for $10 \mathrm{~min}$., and the serum samples were subsequently stored in $1.5-\mathrm{mL}$ tubes at $20^{\circ} \mathrm{C}$ until testosterone quantification.

The bulls' total serum testosterone concentration was determined by radioimmunoassay using a commercial Total Testosterone Coat-A-Count ${ }^{\circledR}$ 
kit (Siemens) and quantified in a gamma counter (Cobra II Auto-gamma, Packard BioScience Company, USA).

Data on the plasma membrane integrity, acrosomal membrane integrity and mitochondrial membrane potential, progressive motility, vigor and wave motion of the sperm were square-root transformed $(\mathrm{X}+1)$, and the serum testosterone data were logarithmically transformed $(\mathrm{X}+1)$ to normalize these data and were analyzed using the ANOVA of the GLM procedure in SAS (2013). Age was set as a source of variation, and the animal weight was set as a covariate. Tukey's multiple comparisons test in the GLM procedure in SAS (2013) was performed to check for statistically significant differences. The alpha value was set at 0.05 .
Pearson's correlation in the GLM procedure in SAS (2013) was applied to test for associations between sperm plasma membrane integrity, acrosomal membrane integrity and mitochondrial membrane potential, progressive movement, vigor, mass motility of spermatozoa (wave motion), serum testosterone levels, scrotal circumference, and body weight of the bulls. Alpha was set at 0.05 .

\section{RESULTS}

In general, bulls with 18 to 21 months of age exhibited lower sperm activity (motility, vigor, and wave motion) and a smaller scrotal circumference compared to older individuals (Table 1). Basal testosterone levels in 18-19 month old bulls was higher than in those between 20 to 23 months old, but similar to those of 24 to 27 month old bulls (Table 1).

Table 1. Mean values ( $\pm \mathrm{sd}$ ) for physical characteristics of semen (progressive motility, vigor, and wave motion), scrotal circumference and testosterone concentration in Nelore bulls

\begin{tabular}{|c|c|c|c|c|c|}
\hline \multirow[b]{2}{*}{$\begin{array}{l}\text { Age } \\
\text { (months) }\end{array}$} & \multicolumn{3}{|c|}{ Physical characteristics of semen } & \multirow[b]{2}{*}{$\begin{array}{l}\text { Scrotal } \\
\text { circumference } \\
(\mathrm{cm})\end{array}$} & \multirow[b]{2}{*}{$\begin{array}{l}\text { Serum } \\
\text { testosterone } \\
(\mathrm{ng} / \mathrm{mL})\end{array}$} \\
\hline & $\begin{array}{l}\text { Sperm } \\
\text { progressive } \\
\text { motility }{ }^{1} \\
(\%)\end{array}$ & $\begin{array}{l}\text { Sperm vigor }{ }^{1} \\
(0 \text { to } 5)\end{array}$ & $\begin{array}{l}\text { Wave motion } \\
(0 \text { to } 5)\end{array}$ & & \\
\hline $18-19$ & $4.95 \pm 0.34^{\mathrm{D}}$ & $1.51 \pm 0.05^{\mathrm{B}}$ & $1.32 \pm 0.06^{\mathrm{B}}$ & $25.6 \pm 2.5^{\mathrm{C}}$ & $2.01 \pm 0.70^{\mathrm{A}}$ \\
\hline $20-21$ & $6.23 \pm 0.34^{\mathrm{C}}$ & $1.83 \pm 0.05^{\mathrm{A}}$ & $1.46 \pm 0.06^{\mathrm{AB}}$ & $27.3 \pm 2.3^{\mathrm{B}}$ & $1.43 \pm 0.35^{\mathrm{C}}$ \\
\hline $22-23$ & $8.16 \pm 0.35^{\mathrm{A}}$ & $1.97 \pm 0.05^{\mathrm{A}}$ & $1.77 \pm 0.06^{\mathrm{A}}$ & $28.4 \pm 2.1^{\mathrm{B}}$ & $1.72 \pm 0.45^{\mathrm{B}}$ \\
\hline $24-25$ & $8.22 \pm 0.35^{\mathrm{AB}}$ & $1.91 \pm 0.05^{\mathrm{A}}$ & $1.74 \pm 0.06^{\mathrm{A}}$ & $30.3 \pm 2.0^{\mathrm{A}}$ & $1.98 \pm 0.34^{\mathrm{A}}$ \\
\hline $26-27$ & $7.12 \pm 0.35^{\mathrm{BC}}$ & $1.89 \pm 0.05^{\mathrm{A}}$ & $1.72 \pm 0.06^{\mathrm{AB}}$ & $31.1 \pm 1.9^{\mathrm{A}}$ & $2.18 \pm 0.46^{\mathrm{A}}$ \\
\hline
\end{tabular}

${ }^{\mathrm{I}}$ Square root transformed data $(\mathrm{X}+1)$ on sperm progressive motility, sperm vigor, and wave motion.

Different letters in a same column indicate differences in sperm functionality and serum testosterone concentration between the ages of the bulls $(\mathrm{P}<0.01)$.

Bulls from 18 to 26 months of age exhibited the highest amount of sperm with damaged membranes [DMe, IA, LM and DMe, DA, LM], whereas sperm older than 26 mo exhibited the highest occurrence of intact sperm [IMe, IA, LM] (Fig. 1). Sperm with damaged membranes and intact acrosomes [DMe, IA, LM] became less frequent with cattle age and had the lowest rate in the oldest bulls (Fig. 1). The concentration of sperm with damaged acrosomal membranes
[IMe, DA, LM and DMe, DA, LM] did not differ significantly $(\mathrm{P}>0.05)$ between bulls in puberty (18-19 months) and at 26-27 months of age (Figure 1).

In the winter and spring when the cattle were 2223 and 24-25 months old, respectively, the proportion of sperm with intact membranes [IMe, DA, LM] increased, and the proportion with damaged acrosomal membranes [DMe, DA, LM] decreased (Figure 1). The concentration of sperm with intact membranes and a high mitochondrial potential [IMe, IA, HM] was low during the entire experiment (Figure 1). 


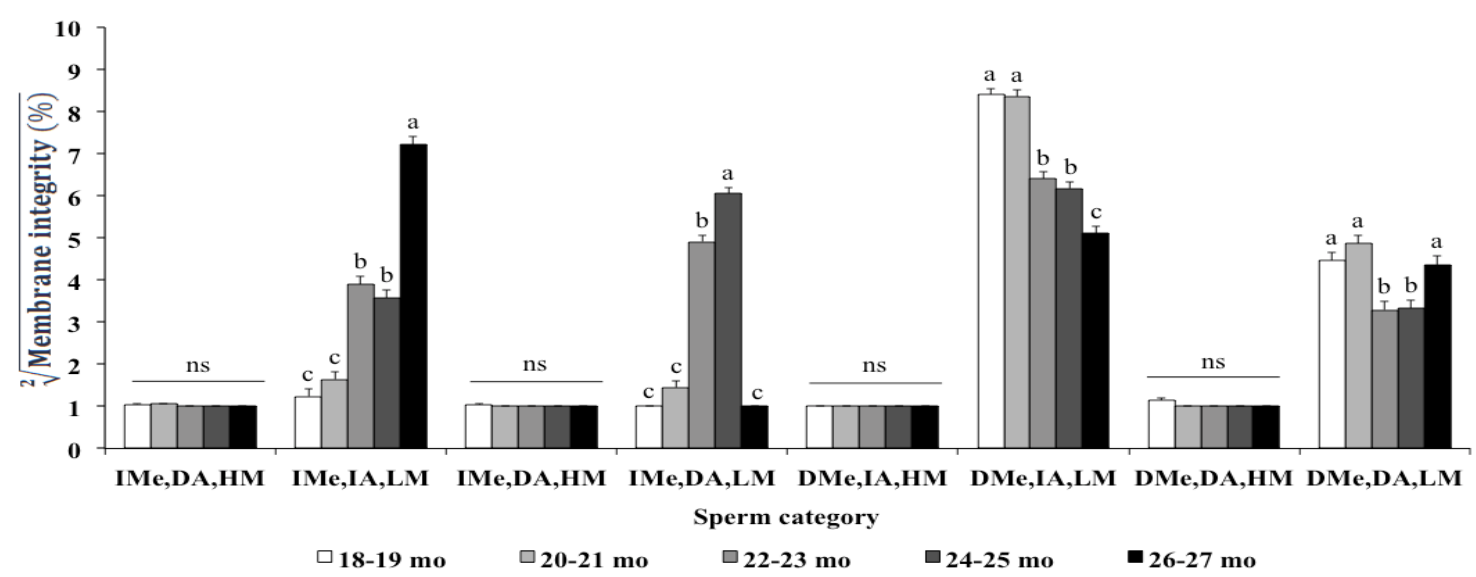

Figure 1. Effect of sexual maturation on the frequency (mean + SD) of Nellore cattle sperm with intact membranes (data pooled within each lot, $\mathrm{N}=60$ bulls/age). Sperm were classified into 8 integrity categories considering the combination of intact (IMe) or damaged plasma membrane (DMe), intact (IA) or damaged acrosome membrane (DA), and high (HM) or low (LM) mitochondrial membrane potential. Different letters in a same category indicate significant differences among the seasons $(\mathrm{P}<0.01)$; ns $=$ non-significant $(\mathrm{P}>0.05)$.

The correlation tests (Table 2) showed that the occurrence of sperm with damaged membranes [DMe, IA, LM; DMe, DA, HM and DMe, DA, LM] was negatively associated with sperm motility, vigor and wave motion. Sperm membrane integrity was positively correlated with scrotal circumference (Table 2).

Table 2. Pearson's Correlation coefficient between spermatozoa membrane integrity, progress motility, vigor, wave motion, serum testosterone, and scrotal circumference of Nelore bulls

\begin{tabular}{llllllll}
\hline & \multicolumn{7}{c}{ Coefficient of Correlation } \\
\cline { 3 - 7 } Sperm category & $\mathrm{N}$ & $\begin{array}{l}\text { Sperm } \\
\text { progress } \\
\text { motility }\end{array}$ & $\begin{array}{l}\text { Sperm } \\
\text { vigor }\end{array}$ & $\begin{array}{l}\text { Wave } \\
\text { motion }\end{array}$ & $\begin{array}{l}\text { Serum } \\
\text { Testosterone }\end{array}$ & $\begin{array}{l}\text { Scrotal } \\
\text { Circumference }\end{array}$ & $\begin{array}{l}\text { Body } \\
\text { weight }\end{array}$ \\
\hline IMe, IA, HM & 281 & -0.02 & -0.03 & 0.01 & 0.01 & -0.10 & - \\
IMe, IA, LM & 281 & $0.24^{* *}$ & $0.23^{* *}$ & $0.27^{* *}$ & $0.24^{* *}$ & $0.52^{* *}$ & $0.15^{* *}$ \\
IMe, DA, HM & 281 & $0.05^{* *}$ & 0.09 & 0.10 & 0.07 & 0.01 & -0.09 \\
IMe, DA, LM & 281 & $0.31^{* *}$ & $0.22^{* *}$ & $0.21^{* *}$ & -0.04 & $0.17^{* *}$ & $0.29^{* *}$ \\
DMe, IA, HM & 281 & $0.02^{*}$ & 0.03 & 0.02 & -0.07 & -0.07 & -0.05 \\
DMe, IA, LM & 281 & $-0.14^{*}$ & -0.09 & $-0.18^{* *}$ & $-0.13^{*}$ & $-0.45^{* *}$ & - \\
DMe, DA, HM & 281 & $-0.12^{* *}$ & $-0.11^{*}$ & -0.07 & -0.06 & -0.05 & $0.56^{* *}$ \\
DMe, DA, LM & 281 & $-0.26^{* *}$ & $-0.22^{* *}$ & $-0.18^{* *}$ & $-0.14^{* *}$ & $-0.15^{* *}$ & -0.07 \\
\hline
\end{tabular}

Intact (IMe) or damaged plasma membrane (DMe), intact (IA) or damaged acrosome membrane (DA), and high (HM) or low (LM) mitochondrial membrane potential.

* Significant correlation at $P<0.05$.

${ }^{* *}$ Significant correlation at $P<0.01$.

Most sperm categories were not affected by lot. Bulls from $\mathrm{L}_{1}, \mathrm{~L}_{2}$ and $\mathrm{L}_{3}$ showed similar concentrations of sperm with intact membranes [IMe, IA, LM] $(\mathrm{P}>0.05)$, and lots $\mathrm{L}_{1}, \mathrm{~L}_{2}$ and $\mathrm{L}_{4}$ had a similar content of sperm with damaged plasma membranes [DMe, DA, LM] $(\mathrm{P}>0.05)$ (Figure 2). 


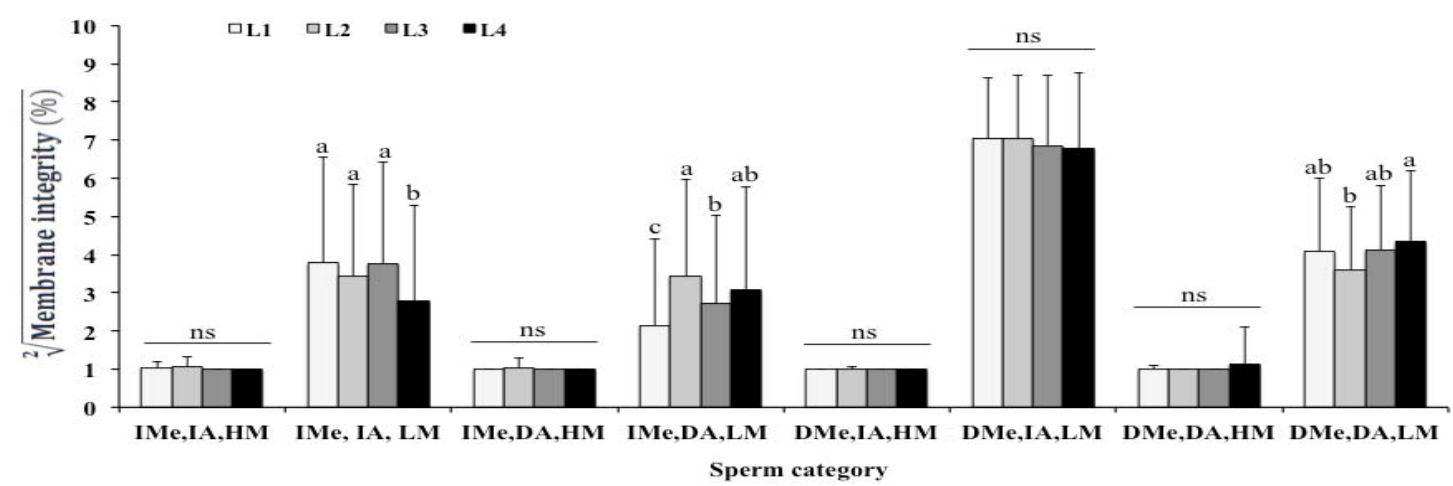

Figure 2. Effect of lot on the frequency (mean + SD) of intact plasma or acrosomal membrane in Nelore bull sperm. Sperm were classified into 8 integrity categories considering the combination of intact (IMe) or damaged plasma membrane (DMe), intact (IA) or damaged acrosome membrane (DA) and high (HM) or low (LM) mitochondrial membrane potential. Different letters in a same category indicate significant differences among the lots $(\mathrm{P}<0.01)$; ns = non-significant $(\mathrm{P}>0.05)$.

\section{DISCUSSION}

The characteristics of semen from Nellore bulls in puberty (18-19 months of age) were compatible with this phase of their reproductive development, and as such, the sperm exhibited low progressive motility, vigor, and wave motion. Earlier studies also reported low sperm concentration and progressive motility during bull puberty (Martins et al., 2011; Costa and Silva et al., 2013). With bull maturity, however, sperm quality improved, which is likely related to changes in the hormonal profile.

Hormonal changes occurring throughout sexual development are a remarkable aspect of the onset of puberty in bulls. At this stage, the hypothalamic-pituitary-gonadal axis releases peaks of gonadotropin-releasing hormone (GnRH) that stimulate the production of follicle stimulating hormone (FSH) and luteinizing hormone $(\mathrm{LH})$, which triggers testosterone release in pulses of low-intensity and frequency (Coulter and Foote, 1979; Chandolia et al., 1987; Pineda, 1989; Bagu et al., 2006) and mitotic activity of Sertoli cells (Buzzard et al., 2002; Sharpe et al., 2003). LH also stimulates Sertoli cells to differentiate and synthetize growth factors, which promote Leydig cell maturation (Sharpe, 1994; Walker and Cheng, 2005). Mature Leydig cells respond to the increasing LH stimulus synthetizing primarily testosterone, which is essential for bull puberty (Amann and Schanbacher, 1983; Amann et al., 1986). With 18-19 mo of age, the elevated basal testosterone levels (Table 2) likely triggered a negative feedback, decreasing GnRH and gonadotrophin release and thus lowering Leydig cell stimulation and testotosterone production (Amann and Schanbacher, 1983). This response was also observed in studies on the sexual development of Nelore (Moura et al., 2002) and Angus bulls (Aguiar et al., 2006).

Puberty in Nellore bulls lasts from 18 to 26 months of age, and at this stage, they exhibited a low amount of sperm with intact membranes and a high amount of sperm with damaged membranes. This likely occurred because the lumen of the seminiferous tubules and the Sertoli cells were still too immature to produce the fluid required for spermatogenesis (Coulter and Foote, 1979). The occurrence of damaged membranes was shown to be associated with low levels of testosterone, which accounts for the onset and maintenance of spermatogenesis. Although testosterone is correlated with the occurrence of sperm with intact membranes, the high testosterone levels in 18-19 month bulls did not prevent sperm damage. The correlation between sperm integrity and scrotal circumference also results from the maturity of the bull and the increase in testosterone production.

The association between membrane damage and sperm activity from puberty to the age of 26 months is explained by severe biophysical and biochemical changes. Sperm progressive motility, vigor and wave motion are activities that require a considerable amount of energy that 
is produced in the middle portion of the sperm cell in the form of adenosine triphosphate (ATP) (Amann and Pickett, 1987; Barth and Oko, 1989; Graham, 1996). When the sperm membrane is damaged, its permeability increases causing the loss of intracellular components that reduces the metabolic activity of the sperm (Amann and Pickett, 1987; Graham, 1996), including sperm motility, vigor, and wave motion. In fact, the bulls tested in this study (especially the newly sexually mature bulls) showed a correlation between sperm activity and membrane integrity.

An aspect to be considered is that, differently from the sperm plasma membrane, the integrity of the acrosomal membrane was not affected by the sexual maturation of the bull. The sperm acrosome is formed in the seminiferous tubules during spermatogenesis, where germ cells differentiate into mature spermatozoa (Barth and Oko, 1989), or during sperm storage in the epididymis. Defects in the sperm acrosome can cause sub-fertility or infertility because they compromise the sperm-oocyte fusion, even though the sperm membrane is fixed to an oocyte in the free zone and fertilization occurs (Hafez, 2004).

The occurrence of intact sperm with a high mitochondrial membrane potential was low, probably because the experiment ended at the early maturation of the bulls, when testes were still in growth phase (Brito et al., 2004). The results suggest that the sperm of Nelore bulls only reaches full mitochondrial membrane potential at the end of sexual maturity, when the bulls become adults.

The positive association between body weight and sperm membrane integrity and scrotal circumference indicate that sperm quality is related to the development of the bulls and their testicles. Therefore, the sperm become complete after the total development of the seminiferous tubes, which in the present study was probably accomplished when the bulls reached $388.80 \pm$ $29.49 \mathrm{~kg}$ body weight and $30.3 \pm 2.0 \mathrm{~cm}$ scrotal circumference. However, excessive body weight is not beneficial for sperm membrane integrity, as shown by the negative correlation sperm of the class [IMe, IA, HM] and body weight (Tab. 2 ), which indicates that obesity can be related to the prevalence of damaged sperm membrane. Obesity possibly changes body and testicle thermoregulation because of the fat accumulated in the body and in the spermatic cord of bulls. The accumulated fat compromises thermal control in the pampiniform plexus by making heat exchanges between blood and the environment difficult, thereby inducing testicular hyperthermia and possibly testicular degeneration. In addition, it decreases testosterone levels, semen production and epididymal sperm reserves and increases the rate of sperm anomalies (Coulter and Kozub, 1984; Silva, 2002).

Semen collection during different seasons allowed the evaluation of the effect on sperm quality. In the winter and spring, the proportion of sperm with intact membranes increased whereas that of sperm with damaged acrosomal membranes decreased. The deterioration of the sperm membranes in the summer could occur because of heat stress, given that overheating is detrimental to spermatogenesis, and therefore the testis temperature should be maintained between 4 and $6^{\circ} \mathrm{C}$ below body temperature (Kastelic et al., 1997). In this study, environmental temperatures were above $30^{\circ} \mathrm{C}$ in the summer, which possibly compromised testis thermoregulation and membrane integrity. This suggests that although Nelore bulls are cattle breed more adapted to a tropical climate; they experience thermal stress on hot summer days that compromises sperm quality. Chacur et al. (2014) also reported lower rates of defects in Nelore sperm in the winter, and Orgal et al. (2012) found a similar result in Holstein Friesian bull semen.

The genetic variability among the lots also affected the rate of sperm membrane integrity, although this effect was not very pronounced. In fact, $75 \%$ of the Nelore bulls had similar concentrations of sperm with intact membranes (lots $\mathrm{L}_{1}, \mathrm{~L}_{2}$ and $\mathrm{L}_{3}$ ) and $75 \%$ similar content of sperm with damaged membranes (lots $\mathrm{L}_{1}, \mathrm{~L}_{3}$ and $\left.\mathrm{L}_{4}\right)$.

The findings obtained in this study demonstrate that Nelore bulls in early puberty have a small proportion of sperm with intact membranes and that they exhibit low sperm motility, vigor, and wave motion). In contrast, when the bulls reach sexual maturity, they produce a high amount of sperm with intact membranes. The acrosomal membrane was not affected by the sexual 
maturation of the bulls. The genetic variability of the bulls had a minor influence on the sperm membrane integrity.

\section{ACKNOWLEDGEMENTS}

The authors thank Fundação de Amparo a Pesquisa do Estado de São Paulo (FAPESP) for sponsoring the study and TORTUGA, the Companhia Zootécnica Agrária, for its support.

\section{REFERENCES}

AGUiAR, G.V.; ARAUJO, A.A.; MOURA, A.A.A. Desenvolvimento testicular, espermatogênese e concentrações hormonais em touros Angus. Rev. Bras. Zootec., v.35, p.1629-1638, 2006.

AMANN, R.P.; SCHANBACHER, B.D. Physiology of male reproduction. J. Anim. Sci., v.57, p.380-403, 1983.

AMANN, R.P.; WISE, M.E.; GLASS, J.D. Prepubertal changes in the hypothalamic Pituitary axis of Holstein bulls. Biol. Reprod., v.34, p.71-80, 1986.

AMANN, R.P.; PICKETT, B.W. Principles of cryopreservation and a review of cryopreservation of stallion spermatozoa. $J$. Equine Vet. Sci. v.7, p.145-173, 1987.

BAGU, E.T.; COOK, S.J.; HONARAMOOZ, A. et al. Changes in sérum luteinizing hormone (LH) concentrations in response to luteinizing hormone releasing hormone (LHRH) in bull calves that attained puberty early or late. Theriogenology, v.66, p.937-944, 2006.

BARTH, A.D.; OKO, R.J., Normal bovine spermatogenesis and sperm maturation. In: BARTH, A.D., OKO, R.J. (Eds.). Abnormal morphology of bovine spermatozoa. Ames: Iowa State University Press, 1989. p.19-88.

BRITO, L.F.C.; SILVA, A.D.E.F.; UNANIAN, M.M. et al. Sexual development in early and late-maturing Bos indicus and Bos indicus x Bos taurus crossbred bulls in Brazil. Theriogenology, v.62, p.1198-1217, 2004.

BUZZARD, J.J.; MORRISON, J.R.; O'BRYAN, M.K. et al. Developmental expression of thyroid hormone receptors in the rat testis. Biol. Reproduct., v.62, p.664-669, 2000.
CELEGHINI, E.C.C.; ARRUDA, R.P.; ANDRADE, A.F.C. et al. Practical techniques for bovine sperm simultaneous fluorimetric assessment of plasma, acrosomal and mitochondrial membranes. Reprod. Domest Anim., v.42, p.479-88, 2007.

COSTA SILVA, E.V.; FERREIRA, B.X.; QUEIROZ, V.L.D. et al. Precocidade sexual de touros a campo em condições tropicais. Rev. Bras. Reprod. Anim., v.37, p.97-104, 2013.

COULTER, G.H.; KOZUB, G.C. Testicular development, pididymal sperm reserves and semen quality in two-year-old Hereford and Angus bulls. J. Anim. Sci., v.59, p.432-440, 1984.

COULTER, G.H.; FOOTE, R.H. Bovine testicular mesurements as indicators of reproductive performance and their relationship to reproductive traits in cattle: a review. Theriogenology, v.11, p.297-311, 1979.

CHACUR, M.G.M.; REIS, J.D.A.; TAVARES, L.S. et al. Influência das épocas do ano na morfometria testicular e epididimária, características do sêmen e proteínas do sêmen em SDS-PAGE em zebus e taurinos. Acta Sci. Vet., v.42, p.1174, 2014.

CHANDOLIA, R.K.; HONARAMOOZ, A.; OMEKE, B.C. et al. Assessment of development of the testes and accessory glands by ultrasonography in bull calves and associated endocrine changes. Theriogenology, v.48, p.119132, 1987.

FLESH, F.M.; GADELLA, B.M. Dynamics of the mammalian sperm membrane in the process of fertilization. Biochim. Biophys. Acta, v.1469, p.197-235, 2000.

FERNANDES, C.E.; DODE, M.A.; PEREIRA, D. et al. Effects of scrotal insulation in Nellore bulls (Bos taurus indicus) on seminal quality and its relationship with in vitro fertilizing ability. Theriogenology, v.70, p.1560-1568, 2008.

FRENEAU, G.E., VALE FILHO, V.R., MARQUES, A.P. et al. Puberdade em touros Nelore criados em pasto no Brasil: características corporais, testiculares e seminais e de índice de capacidade andrológica por pontos. Arq. Bras. Med. Vet. Zootec., v.58, p.1107-1115, 2006. 
GRAHAM, J.K. Cryoservetion of stallion spermatozoa. Vet. Clin. North Am. Equine Pract., v.12, p.131-147, 1996.

GUIA prático para a correta suplementação pecuária. Sorocaba, SP: ASBRAM, 2003.

HAFEZ, E.S.E., Anatomia da reprodução masculina. In: HAFEZ, E.S.E, HAFEZ, B. (Eds.). Reprodução animal. São Paulo: Manole, 2004. p.3-12.

KASTELIC, J.P.; COOK, R.B.; COULTER, G.H. Contribuition of the scrotum, testes and testicular artery to scrotal/testicular thermoregulation in bulls at two ambient temperatures. Anim. Reprod. Sci., v.45, p.255-61, 1997.

MARTINS, J.A.M.; SOUZA, F.A.; FERREIRA, M.B.D. et al. Desenvolvimento reprodutivo de tourinhos Gir selecionados para produção de leite. Arq. Bras. Med. Vet. Zootec., v.63, p.12771286, 2011.

MIES FILHO, A. Reprodução dos animais. Porto Alegre: Sulina, 1987. p.98-132.

MINERALS. In: NUTRIENT requirements of beef cattle. Washington, DC: Natl. Acad. Press, 2000. p. 54-74.

MOURA, A.A.A.; RODRIGUES, G.C.; MARTINS FILHO, R. Desenvolvimento ponderal e testicular, concentrações periféricas de testosterona e características de abate em touros da raça Nelore. Rev. Bras. Zootec., v.31, p.934-943, 2002.

NETO, T.M., CASTILHO, E.F.C., PINHO, R.O., Puberdade e maturidade sexual em touros jovens da raça Simental, criados sob regime extensivo em clima tropical. Rev. Bras. Zootec., v.40, p.1917-1925, 2011.
ORGAL, S.; ZERON, Y.; ELIOR, N. et al. Season-induced changes in bovine sperm motility following a freeze-thaw procedure. $J$. Reprod. Dev., v.58, p.212-218, 2012.

PINEDA, M.H. Male reproduction. In: MCDONALD, L.E.; PINEDA, M.H. (Eds.). Veterinary endocrinology and reproduction. Philadelphia: Lea \& Febiger, 1989. p.261-302.

PROCEDIMENTOS para exame andrológico e avaliação de semen animal. Belo Horizonte: CBRA, 1992.

REIS, L.S.L.S.; RAMOS, A.A.; CAMARGOS, A.S. et al. Effect of manganese supplementation on the membrane integrity and the mitochondrial potential of the sperm of grazing Nelore bulls. Anim. Reprod. Sci., v.150, p.1-6, 2014.

SAS Institute Inc. Software SAS/STATS [computer program], 2013.

SHARPE, R.M. Regulation of spermatogenesis. In: KNOBIL, E.; NEIL, J.D. (Eds.). The physiology of reproduction. New York: Raven Press, 1994. p.1363-1434.

SHARPE, R.M.; MCKINNELL, C.; KIVLIN, C. et al. Proliferation and functional maturation of Sertoli cells, and their relevance to disorders of testis function in adulthood. Reproduction, v.125, p.769-84, 2003.

SILVA, A.E.D.F. Seleção de touros: puberdade, maturidade e fatores envolvidos na fertilidade. In: DODE, M.A.N. Curso de andrologia. Brasilia: Embrapa Recursos Genéticos e Biotecnología, 2002. p.98-127.

WALKER, W.H.; CHENG, J. FSH and testosterone signaling in Sertoli cells. Reproduction, v.130, p.15-28, 2005. 